\title{
Statistical Variation of Physico-Chemical Properties of Shallow Wells Used for Agricultural Activities in an Agrarian Community, North Central Nigeria
}

\author{
John Jiya Musa ${ }^{1 *}$, Martins Yusuf Otache1, Elijah TsadoMusa², Michael Eneojo Omale, \\ Ibrahim Ibrahim Yahuza Yerima1
}

${ }^{1}$ Department of Agricultural and Bioresources Engineering, Federal University of Technology, Minna, Nigeria

${ }^{2}$ Central Research Laboratory, University of Ilorin, Ilorin, Nigeria

${ }^{3}$ Psychometrics Department, National Examination Council, Minna, Nigeria

Email: *johnmusa@futminna.edu.ng

How to cite this paper: Musa, J.J., Otache, M.Y., Musa, E.T., Omale, M.E. and Yerima, I.I.Y. (2019) Statistical Variation of Physico-Chemical Properties of Shallow Wells Used for Agricultural Activities in an Agrarian Community, North Central Nigeria. Open Access Library Journal, 6: e5683.

https://doi.org/10.4236/oalib.1105683

Received: August 8, 2019

Accepted: September 26, 2019

Published: September 29, 2019

Copyright $\odot 2019$ by author(s) and Open Access Library Inc.

This work is licensed under the Creative Commons Attribution International License (CC BY 4.0).

http://creativecommons.org/licenses/by/4.0/

\begin{abstract}
Water quality is gradually falling due to human activities, thus making clean water for both domestic and agricultural activities scarce. Population growth is expected to directly or indirectly move up from its current status by about $55 \%$, thus increasing water stress or severe water scarcity over the next generation. This study is aimed at statistically ascertaining and determining the physico-chemical properties of some hand-dug wells in Niykangbe, an agrarian community in Nigeria. A total of twenty five samples were collected for each year during the dry season for a period of three years. Replicate samples were collected on monthly bases for a period of five months during the years 2014, 2015 and 2016. The results obtained indicated that aluminum, cyanide and manganese were not present in the water samples. The $\mathrm{pH}$ ranged between 7.10 and 7.70, electric conductivity ranged between 157 and $467 \mu \mathrm{s} / \mathrm{cm}$ and the temperature ranged between $30^{\circ} \mathrm{C}$ and $33^{\circ} \mathrm{C}$. The nitrate content ranged between 5.00 and $67.30 \mathrm{mg} / \mathrm{l}$ while nitrite ranged between 0.02 and $0.09 \mathrm{mg} / \mathrm{l}$. The analysis should be that most of the parameters were still within the recommended standards of NSDWQ and WHO. It was concluded that intermittent test is carried out to ascertain the level of fitness of the various water samples for both domestic and agricultural use.
\end{abstract}

\section{Subject Areas}

Hydrology

\section{Keywords}

Chemical, Physical, Quality, Water, Well 


\section{Introduction}

Water, according to several researchers is said to be one of the most important natural resources as it is seen as a key to prosperity and wealth [1] [2] [3]. However, water quality is gradually falling due to human activities thus making clean water for both domestic and agricultural activities scarce [4]-[10]. Population growth is expected to directly or indirectly move up from its current status by about $55 \%$ thus increasing water stress or severe water scarcity over the next generation [7] [11]-[16]. Genuine concerns are therefore raised about future quality of water because of the important role water plays in sustainable development and quality of life.

Over time many have believed that groundwater is the most reliable source of fresh water to most communities which is the most common renewable resource in the savannah region of Nigeria which is as a result of the seasonal rainfall which is observed [17]. With the seasonal rainfall, groundwater recharge is limited to infiltration process which occurs during the period. In most developing countries like Nigeria, individuals provide various forms of water sources for both domestic and agricultural use [5] [18] [19]. This is because of the unavailability of the pipe borne water supply. These forms of water sources usually include harvested rain water, hand-dug (shallow) wells, boreholes (deep wells), springs, streams and rivers.

The quality of such water sources over time has been determined by several factors such as concentration of dissolved oxygen, bacteria levels, the amount of salt (or salinity), or the amount of material suspended in the water (turbidity) [20]-[25]. The distribution of these quality parameters is believed to be controlled by complex processes of chemical composition. Such chemical composition does not only depend on natural factors such as the lithology of the aquifer, the quality of recharge water and the type of interaction between water and aquifer, but also on human activities, which can alter these ground water systems either by polluting them or by changing the hydrological cycle [17]. In some bodies of water, the concentration of microscopic algae and quantities of pesticides, herbicides, heavy metals, and other contaminants may also be measured to determine water quality [26] [27].

The present and predicted increase in groundwater withdrawals, its unprecedented importance for human consumption globally, and the emerging threats from escalated and unplanned use and degradation especially in the developing countries point the need for intensified efforts to cope with the imbalances. Despite these facts, there is little intervention by governments in developing countries. Sufficient knowledge, awareness and understanding of groundwater resource and their management are missing in these countries, as well as in international communities [28]. The monitoring of water quality parameters is of utmost importance in environmental protection policy as it is believed to provide a representative and reliable estimate of ground waters quality [29]. Thus, standard monitoring processes and programs which include frequent water 
sampling at varying locations are employed to inform the society of the standard and quality of water being used for domestic and agricultural purposes.

Changes in the physical and chemical parameters of drinking water have overtime being stated to affect the $\mathrm{pH}$, colour, salinity, dissolved oxygen, total solutes, alkalinity, hardness and electrical conductivity of the water beyond the Nigerian Water Drinking Quality Standard (NWDQS) and WHO specified accepted limits [30] [31], thus, causing different types and level of water borne diseases including diarrhea, cholera, typhoid fever, shigellosis, giardiasis, schistosomiasis, hepatitis, cryptosporidiosis, onchocerciasis and dracuncuculiasis [32]. This study is aimed at statistically ascertaining and determining the physico-chemical properties of some hand-dug wells in an agrarian community in Nigeria.

\section{Materials and Method}

\subsection{Study Site}

Nyikangbe community is one of the rapidly growing twenty-five (25) neighborhoods of Minna, Nigeria. Niger state is located in the North Central area of Nigeria with an estimated population of a little above one million. Minna having an average temperature of $31^{\circ} \mathrm{C}$ and wind speed at $10 \mathrm{~km} / \mathrm{h}$ lies on the geographical coordinates of latitude $9^{\circ} 36^{\prime} 50^{\prime \prime}$ north and longitude $6^{\circ} 33^{\prime} 24^{\prime \prime}$ east. The average elevation of Minna is $272 \mathrm{~m}$ and altitude 1007 feet above the sea level [1] (Figure 1 \& Figure 2).

\subsection{Sample Collection}

The same process of sample collection was followed as identified by [1] [33] for the study location and points. A total of 25 samples were collected, five each from the various shallow wells with replicates at once a month over a period of five months. This period spanned between the months of January, February, March, April and May of the years 2014, 2015 and 2016 which represented the pre-monsoon period of the same year. This did not cover the seasonal variation

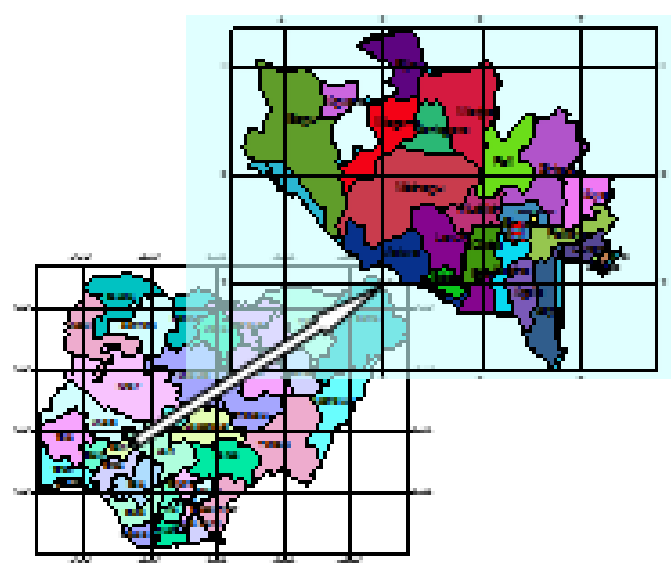

Figure 1. Map of Nigeria showing an extract of Niger State. 


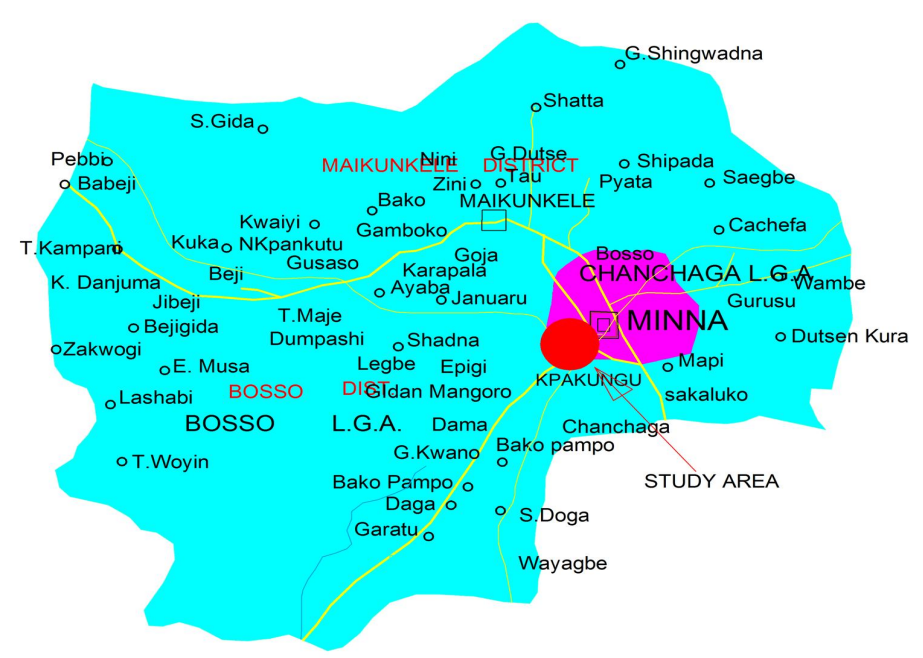

Figure 2. Map of Bosso Local Government Area with the study location dotted red.

of the study period but the pick period when water is being used for both domestic and agricultural purposes. This is similar to the works of [31]. This does not cover the different litho units of the zone. Samples from these sources of underground water were collected during pick period of the dry season in a $1 \mathrm{li}$ ter sterilized bottle with each carefully labeled and kept in an iced box. The samples collected were analyzed for major cations like, $\mathrm{Ca}$ and $\mathrm{Mg}$ by Titrimetry, $\mathrm{Na}$ and $\mathrm{K}$ by Flame photometer ( $\mathrm{CL} 378$ ); anions, $\mathrm{Cl}$ and $\mathrm{HCO}_{3}$ by Titrimetry, $\mathrm{SO}_{4}$, $\mathrm{PO}_{4}$, and $\mathrm{H}_{4} \mathrm{SiO}_{4}$ by Spectrophotometer (SL 171 minispec). EC and $\mathrm{pH}$ were determined in the field using electrode (Eutech). TDS was also measured in situ by TDS portable electrode model TDS Testr11+ (multirange). The analyses were done by adopting standard procedures as recommended by [34] [35]. Table 1 shows the geographical location of the various studied wells in Nyikangbe agrarian community.

\subsection{Data Analysis}

Each set of data from the various wells were characterized by a large number of chemical and physical variables, making the study area a multivariate problem. This is similar to the works of [31]. The results collected from the laboratory were statistically analyzed using Statistical Analysis Software (SAS) package (1985). This was used for the determination of the correlation matrix for the obtained data. This further allowed for the grouping of groundwater samples and the making of correlations between chemical, physical parameters and groundwater samples. The results of which were compared using least significant difference (LSD, $\mathrm{P}=0.05$ ) procedure [36] [37] [38].

\section{Results}

The analytical results for the physical and chemical water quality parameters of the various groundwater sampled in Nyikangbe community during the dry season for a period of three years is presented in Table 2 and Table 3 respectively. 
Table 1. Geographical location of the studied wells.

\begin{tabular}{ccc}
\hline Well Numbering & Longitude & Latitude \\
\hline W6 & N09 $35782^{\prime}$ & E006 $30474^{\prime}$ \\
W7 & N09 $^{\circ} 35749^{\prime}$ & E006 30 537' \\
W8 & N09 $^{\circ} 35668^{\prime}$ & E006 $30597^{\prime}$ \\
W9 & N09 $^{\circ} 35619^{\prime}$ & E006 $^{\circ} 30517^{\prime}$ \\
W10 & N09 $35584^{\prime}$ & E006 $30800^{\prime}$ \\
\hline
\end{tabular}

Table 2. Chemical analysis of water samples.

\begin{tabular}{|c|c|c|c|c|c|c|c|c|c|c|c|c|c|c|c|}
\hline $\begin{array}{l}\text { Sample } \\
\text { Points }\end{array}$ & Rep & $\begin{array}{l}\text { Nitrate } \\
(\mathrm{mg} / \mathrm{L})\end{array}$ & $\begin{array}{l}\text { Nitrite } \\
(\mathrm{mg} / \mathrm{L})\end{array}$ & $\begin{array}{c}\mathrm{Ch} \\
(\mathrm{mg} / \mathrm{L})\end{array}$ & $\begin{array}{c}\mathrm{Cu} \\
(\mathrm{mg} / \mathrm{L})\end{array}$ & $\begin{array}{c}\mathrm{Fe} \\
(\mathrm{mg} / \mathrm{L})\end{array}$ & $\begin{array}{c}\mathrm{Fl} \\
(\mathrm{mg} / \mathrm{L})\end{array}$ & $\begin{array}{c}\mathrm{SO}_{4} \\
(\mathrm{mg} / \mathrm{L})\end{array}$ & $\begin{array}{c}\mathrm{Mg} \\
(\mathrm{mg} / \mathrm{L})\end{array}$ & $\begin{array}{c}\mathrm{Ca} \\
(\mathrm{mg} / \mathrm{L})\end{array}$ & $\begin{array}{c}\mathrm{TH} \\
(\mathrm{mg} / \mathrm{L})\end{array}$ & $\begin{array}{c}\mathrm{TA} \\
(\mathrm{mg} / \mathrm{L})\end{array}$ & $\begin{array}{c}\mathrm{PO}_{4} \\
(\mathrm{mg} / \mathrm{L})\end{array}$ & $\begin{array}{c}\text { Ammonia } \\
(\mathrm{mg} / \mathrm{L})\end{array}$ & $\begin{array}{c}\mathrm{Na} \\
(\mathrm{mg} / \mathrm{L})\end{array}$ \\
\hline W6 & 1 & 20 & 0.03 & 0.01 & 0.4 & 0.1 & 0.5 & 2.6 & 0.03 & 0.4 & 32 & 18 & 0.1 & 0.25 & 2.5 \\
\hline W6 & 2 & 24 & 0.08 & 0.06 & 0.65 & 0.43 & 0.07 & 3.3 & 0.06 & 0.43 & 96 & 27 & 0.04 & 0.04 & 4.2 \\
\hline W6 & 3 & 26 & 0.02 & 0.02 & 0.52 & 0.76 & 0.57 & 4.2 & 0.08 & 0.76 & 73 & 31 & 0.06 & 0.04 & 2.6 \\
\hline W6 & 4 & 22 & 0.04 & 0.07 & 0.74 & 0.02 & 0.3 & 2.6 & 0.03 & 0.02 & 87 & 49 & 0.02 & 0.08 & 2.1 \\
\hline W6 & 5 & 21 & 0.04 & 0.02 & 0.59 & 0.04 & 0.07 & 2.1 & 0.04 & 0.04 & 79 & 46 & 0.02 & 0.04 & 2.7 \\
\hline W7 & 1 & 16 & 0.06 & 0.02 & 0.85 & 0.07 & 0.14 & 2.7 & 0.05 & 2.6 & 37 & 24 & 0.08 & 0.35 & 2.7 \\
\hline W7 & 2 & 35 & 0.08 & 0.09 & 0.43 & 0.09 & 0.07 & 2.5 & 0.04 & 1.7 & 43 & 67 & 0.08 & 0.4 & 1.5 \\
\hline W7 & 3 & 41 & 0.03 & 0.04 & 0.76 & 0.03 & 0.57 & 1.8 & 0.08 & 1.9 & 52 & 45 & 0.04 & 0.65 & 1.7 \\
\hline W7 & 4 & 32 & 0.04 & 0.06 & 0.38 & 0.06 & 0.3 & 2.9 & 0.04 & 1.8 & 41 & 26 & 0.02 & 0.52 & 4.8 \\
\hline W7 & 5 & 37 & 0.09 & 0.02 & 0.07 & 0.07 & 0.07 & 3.1 & 0.02 & 1.1 & 47 & 31 & 0.09 & 0.09 & 7.3 \\
\hline W8 & 1 & 12.8 & 0.08 & 0.02 & 0.57 & 0.15 & 0.08 & 3.8 & 0.09 & 3.7 & 129 & 96 & 0.9 & 0.8 & 6.4 \\
\hline W8 & 2 & 15 & 0.02 & 0.07 & 0.3 & 0.14 & 0.1 & 2.1 & 0.03 & 4.1 & 104 & 87 & 0.03 & 0.07 & 3.3 \\
\hline W8 & 3 & 17 & 0.04 & 0.02 & 0.07 & 0.7 & 0.4 & 1.9 & 0.08 & 3.8 & 163 & 91 & 0.08 & 0.02 & 4.2 \\
\hline W8 & 4 & 14 & 0.04 & 0.02 & 0.1 & 0.4 & 0.14 & 2.2 & 0.02 & 2.9 & 138 & 101 & 0.02 & 0.02 & 2.6 \\
\hline W8 & 5 & 13.7 & 0.08 & 0.09 & 0.4 & 0.25 & 0.7 & 1.5 & 0.04 & 1.7 & 142 & 107 & 0.04 & 0.09 & 2.1 \\
\hline W9 & 1 & 5 & 0.04 & 0.01 & 0.14 & 0.08 & 0.06 & 0.7 & 0.08 & 0.9 & 68 & 27 & 0.6 & 0.3 & 2.7 \\
\hline W9 & 2 & 35.8 & 0.02 & 0.03 & 0.7 & 0.4 & 0.52 & 2.1 & 0.05 & 1.4 & 72 & 31 & 0.04 & 0.04 & 2.1 \\
\hline W9 & 3 & 42.6 & 0.09 & 0.06 & 0.4 & 0.65 & 0.09 & 1.9 & 0.08 & 1.7 & 63 & 36 & 0.02 & 0.04 & 1.9 \\
\hline W9 & 4 & 45.8 & 0.03 & 0.05 & 0.7 & 0.52 & 0.06 & 1.5 & 0.02 & 2.1 & 58 & 41 & 0.04 & 0.08 & 2.2 \\
\hline W9 & 5 & 52.3 & 0.06 & 0.08 & 0.3 & 0.09 & 0.76 & 1.7 & 0.07 & 1.9 & 67 & 45 & 0.04 & 0.04 & 1.5 \\
\hline W10 & 1 & 10.7 & 0.04 & 0.02 & 0.07 & 0.06 & 0.09 & 4.8 & 0.12 & 2.9 & 93 & 53 & 0.25 & 0.55 & 3.3 \\
\hline W10 & 2 & 57.5 & 0.02 & 0.07 & 0.1 & 0.76 & 0.52 & 7.3 & 0.02 & 2.3 & 88 & 52 & 0.06 & 0.76 & 3.3 \\
\hline W10 & 3 & 54.9 & 0.04 & 0.02 & 0.4 & 0.38 & 0.74 & 5.2 & 0.09 & 2.5 & 46 & 57 & 0.07 & 0.38 & 4.2 \\
\hline W10 & 4 & 67.2 & 0.04 & 0.02 & 0.2 & 0.07 & 0.59 & 6.3 & 0.01 & 2.1 & 79 & 72 & 0.15 & 0.07 & 2.6 \\
\hline W10 & 5 & 67.3 & 0.08 & 0.09 & 0.5 & 0.57 & 0.85 & 4.1 & 0.03 & 2.6 & 69 & 48 & 0.14 & 0.57 & 2.1 \\
\hline
\end{tabular}

Where $\mathrm{Ch}$ is chromium, $\mathrm{Cu}$ is copper, $\mathrm{Fe}$ is Iron, $\mathrm{Fl}$ is Fluoride, $\mathrm{SO}_{4}$ is Sulphate, $\mathrm{Mg}$ is Magnesium, $\mathrm{Ca}$ is Calcium, TH is Total Hardness, TA is Total Alkalinity, $\mathrm{PO}_{4}$ is Phosphate and $\mathrm{Na}$ is Sodium.

The dry season period is categorized as water deficit period as there is no rainfall with a high rate of evapouration and temperature. Statistical Parameters of groundwater samples of study area are summarized in Table 4 and Table 5 while Table 6 and Table 7 presents the least significant values for the chemical and physical properties of the samples collected over a period of three years. 
Table 3. Physical properties of selected shallow wells in Nyikangbe Community.

\begin{tabular}{|c|c|c|c|c|c|c|c|}
\hline Sample point & $\begin{array}{l}\text { Colour } \\
\text { (pt. Co) }\end{array}$ & $\begin{array}{c}\text { Turbidity } \\
\text { (NTU) }\end{array}$ & $\mathrm{SS}(\mathrm{mg} / \mathrm{L})$ & Ec. $(\mu \mathrm{S} / \mathrm{cm}$ & $\mathrm{DS}(\mathrm{mg} / \mathrm{L})$ & Temp. $\left({ }^{\circ} \mathrm{C}\right)$ & $\mathrm{pH}$ \\
\hline W6 & 8.00 & 1.00 & 8.00 & 157.00 & 120.00 & 32.00 & 7.40 \\
\hline W6 & 8.00 & 4.00 & 14.00 & 252.00 & 126.00 & 31.00 & 7.30 \\
\hline W6 & 12.00 & 2.00 & 12.00 & 267.00 & 138.00 & 32.00 & 7.20 \\
\hline W6 & 14.00 & 5.00 & 10.00 & 298.00 & 149.00 & 32.00 & 7.40 \\
\hline W6 & 10.00 & 2.00 & 13.00 & 275.00 & 159.00 & 32.00 & 7.20 \\
\hline W7 & 4.00 & 4.00 & 10.00 & 240.00 & 140.00 & 32.00 & 7.60 \\
\hline W7 & 4.00 & 2.00 & 13.00 & 298.00 & 157.00 & 32.00 & 7.70 \\
\hline W7 & 6.00 & 3.00 & 16.00 & 305.00 & 252.00 & 32.00 & 7.30 \\
\hline W7 & 2.00 & 1.00 & 12.00 & 310.00 & 267.00 & 31.00 & 7.50 \\
\hline W7 & 3.00 & 4.00 & 11.00 & 347.00 & 298.00 & 32.00 & 7.30 \\
\hline W8 & 143.00 & 26.00 & 31.00 & 352.00 & 220.00 & 32.00 & 7.30 \\
\hline W8 & 151.00 & 21.00 & 37.00 & 390.00 & 253.00 & 32.00 & 7.10 \\
\hline W8 & 132.00 & 27.00 & 39.00 & 410.00 & 274.00 & 33.00 & 7.30 \\
\hline W8 & 143.00 & 28.00 & 37.00 & 467.00 & 278.00 & 31.00 & 7.40 \\
\hline W8 & 145.00 & 25.00 & 32.00 & 420.00 & 264.00 & 32.00 & 7.20 \\
\hline W9 & 7.00 & 2.00 & 13.00 & 369.00 & 210.00 & 32.00 & 7.30 \\
\hline W9 & 9.00 & 4.00 & 14.00 & 398.00 & 212.00 & 31.00 & 7.70 \\
\hline W9 & 11.00 & 2.00 & 12.00 & 296.00 & 223.00 & 32.00 & 7.30 \\
\hline W9 & 14.00 & 5.00 & 10.00 & 315.00 & 220.00 & 32.00 & 7.50 \\
\hline W9 & 15.00 & 3.00 & 13.00 & 362.00 & 215.00 & 31.00 & 7.30 \\
\hline W10 & 10.00 & 1.00 & 21.00 & 220.00 & 140.00 & 32.00 & 7.40 \\
\hline W10 & 12.00 & 2.00 & 23.00 & 253.00 & 153.00 & 31.00 & 7.40 \\
\hline W10 & 14.00 & 1.00 & 19.00 & 274.00 & 162.00 & 32.00 & 7.30 \\
\hline W10 & 12.00 & 3.00 & 20.00 & 278.00 & 152.00 & 30.00 & 7.20 \\
\hline W10 & 11.00 & 2.00 & 23.00 & 264.00 & 145.00 & 32.00 & 7.40 \\
\hline
\end{tabular}

Where SS id the suspended solids, Ec is Electrical Conductivity, TDS is Total Dissolved Solid, Temp. is the Temperature, and $\mathrm{pH}$ is the power of Hydrogen.

Table 4. Correlated values for chemical properties of shallow wells in Nyikangbe Community.

\begin{tabular}{|c|c|c|c|c|c|c|c|c|c|c|c|c|c|c|c|}
\hline & 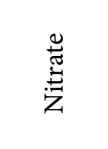 & $\underset{\text { 艺 }}{\stackrel{\Xi}{\Xi}}$ & 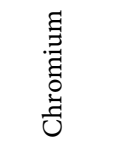 & $\begin{array}{l}\overrightarrow{0} \\
\text { हैं } \\
\text { ठे }\end{array}$ & $\stackrel{0}{0}$ & 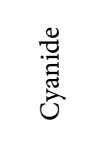 & 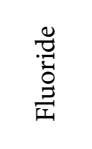 & 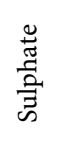 & 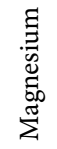 & 竘 & 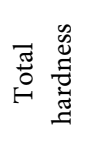 & 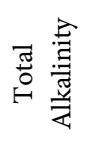 & 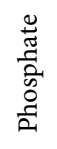 & 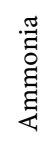 & $\begin{array}{l}\text { 园 } \\
\text { 足 }\end{array}$ \\
\hline Nitrate & 1.0000 & & & & & & & & & & & & & & \\
\hline Nitrite & 0.0459 & 1.0000 & & & & & & & & & & & & & \\
\hline Chromium & 0.3281 & 0.3299 & 1.0000 & & & & & & & & & & & & \\
\hline Copper & 0.0131 & 0.0171 & 0.1428 & 1.0000 & & & & & & & & & & & \\
\hline Iron & 0.2772 & -0.0840 & 0.1120 & 0.1059 & 1.0000 & & & & & & & & & & \\
\hline Cyanide & -0.2381 & -0.1973 & -0.2410 & 0.1735 & 0.0765 & 1.0000 & & & & & & & & & \\
\hline Fluoride & -0.1275 & -0.1652 & 0.2319 & 0.0139 & 0.2334 & 0.0143 & 1.0000 & & & & & & & & \\
\hline
\end{tabular}




\section{Continued}

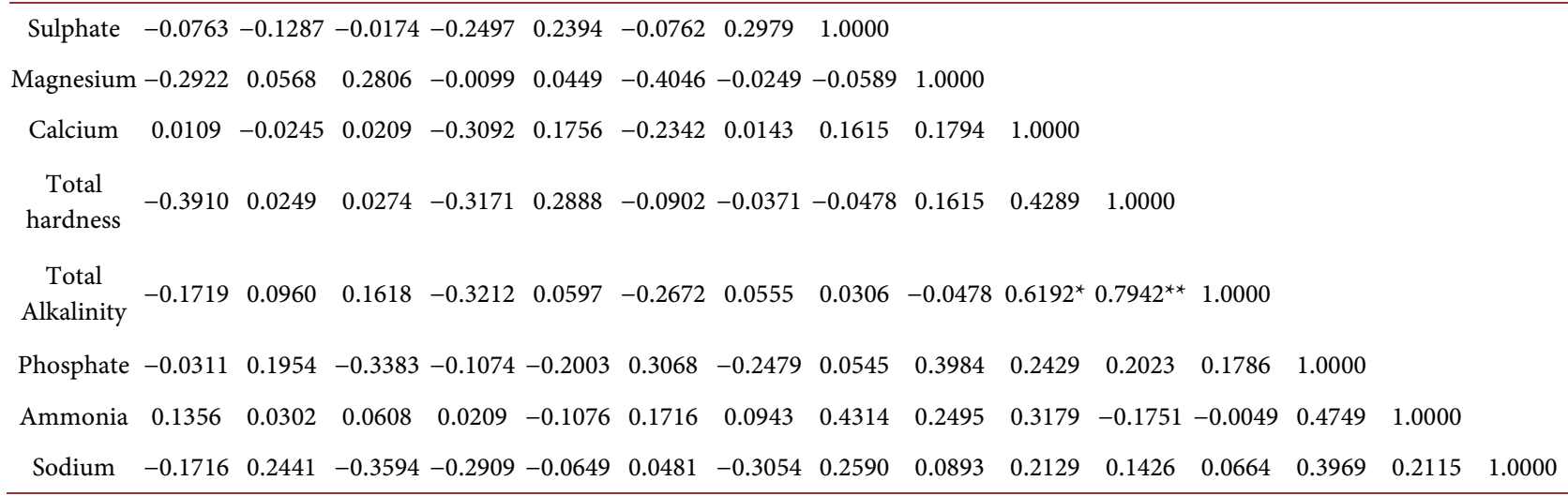

Table 5. Correlated values of physical properties of shallow wells in Nyikangbe Community.

\begin{tabular}{|c|c|c|c|c|c|c|c|}
\hline Parameter & Colour & Turbidity & Suspended Solid & $\begin{array}{c}\text { Electrical } \\
\text { Conductivity }\end{array}$ & $\begin{array}{l}\text { Total Dissolved } \\
\text { Solids }\end{array}$ & Temperature & $\mathrm{pH}$ \\
\hline Colour & 1.0000 & & & & & & \\
\hline Turbidity & $0.9786^{\star \star}$ & 1.0000 & & & & & \\
\hline Suspended Solid & $0.8969^{\star *}$ & $0.8644^{\star \star}$ & 1.0000 & & & & \\
\hline Electrical Conductivity & $0.6782^{*}$ & $0.7194^{\star \star}$ & $0.5902^{*}$ & 1.0000 & & & \\
\hline Total Dissolved Solids & $0.5317^{\star}$ & $0.5703^{\star}$ & $0.4335^{*}$ & $0.8087^{\star *}$ & 1.0000 & & \\
\hline Temperature & 0.2123 & 0.2118 & 0.1117 & 0.0007 & 0.1198 & 1.0000 & \\
\hline $\mathrm{pH}$ & -0.3693 & -0.2799 & -0.3646 & -0.1162 & -0.1592 & -0.0815 & 1.0000 \\
\hline
\end{tabular}

${ }^{*}$ correlation is significant at 0.05 level (2-tailed), (-) indicate no correlation.

Table 6. Least significant difference for the chemical properties of the samples collected over a period of three years.

\begin{tabular}{|c|c|c|c|c|c|c|c|c|c|c|c|c|c|c|c|}
\hline Sample Point & 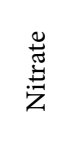 & : & 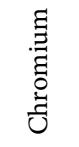 & 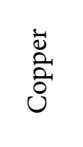 & $\stackrel{0}{0}$ & 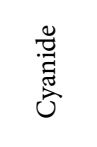 & 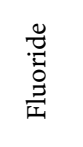 & 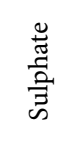 & 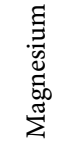 & $\frac{\Xi}{\Xi}$ & ت & 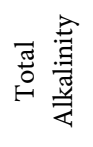 & 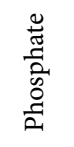 & 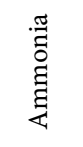 & $\underset{\Xi}{\Xi}$ \\
\hline W6 & 22.60 & 0.04 & 0.36 & 0.58 & 0.27 & 0.0008 & 0.30 & 2.96 & 0.05 & 0.33 & 73.40 & 34.20 & 0.05 & 0.09 & 2.82 \\
\hline W7 & 32.20 & 0.06 & 0.50 & 0.50 & 0.06 & 0.0006 & 0.23 & 2.60 & 0.05 & 1.82 & 44.00 & 38.60 & 0.06 & 0.40 & 3.60 \\
\hline W8 & 14.50 & 0.05 & 0.04 & 0.28 & 0.33 & 0.0002 & 0.28 & 2.30 & 0.05 & 3.24 & 135.20 & 96.40 & 0.21 & 0.20 & 3.72 \\
\hline W9 & 36.30 & 0.05 & 0.05 & 0.45 & 0.35 & 0.0004 & 0.29 & 1.58 & 0.06 & 1.60 & 65.60 & 36.00 & 0.15 & 0.10 & 2.08 \\
\hline W10 & 51.52 & 0.04 & 0.04 & 0.25 & 0.37 & 0.0000 & 0.56 & 5.54 & 0.05 & 2.48 & 75.00 & 56.40 & 0.13 & 0.47 & 3.10 \\
\hline $\mathrm{SE} \pm$ & 6.295 & 0.004 & 0.097 & 0.064 & 0.057 & 0.000 & 0.058 & 0.675 & 0.002 & 0.484 & 15.182 & 11.710 & 0.030 & 0.078 & 0.296 \\
\hline
\end{tabular}

Values with different letters indicate means are significantly different from each other at $\mathrm{p} \leq 0.05$ within each row.

Table 7. Least significant difference for the physical properties of the samples collected over a period of three years.

\begin{tabular}{cccccccc}
\hline $\begin{array}{c}\text { Sample } \\
\text { Point }\end{array}$ & Colour & Turbidity & $\begin{array}{c}\text { Suspended } \\
\text { Solid }\end{array}$ & $\begin{array}{c}\text { Electrical } \\
\text { Conductivity }\end{array}$ & $\begin{array}{c}\text { Total } \\
\text { Dissolved Solids }\end{array}$ & Temperature & pH \\
\hline W6 & $10.40 \mathrm{~B}$ & $2.80 \mathrm{~B}$ & $11.40 \mathrm{C}$ & $249.80 \mathrm{C}$ & $138.40 \mathrm{~B}$ & $31.80 \mathrm{~A}$ & $7.30 \mathrm{~A}$ \\
W7 & $3.80 \mathrm{C}$ & $2.80 \mathrm{~B}$ & $12.40 \mathrm{C}$ & $300.00 \mathrm{~B}$ & $222.80 \mathrm{~A}$ & $31.80 \mathrm{~A}$ & $7.48 \mathrm{~A}$ \\
\hline
\end{tabular}




\section{Continued}

\begin{tabular}{rccccccc}
\hline W8 & $142.80 \mathrm{~A}$ & $25.40 \mathrm{~A}$ & $35.20 \mathrm{~A}$ & $407.80 \mathrm{~A}$ & $257.80 \mathrm{~A}$ & $32.00 \mathrm{~A}$ & $7.26 \mathrm{~A}$ \\
W9 & $11.20 \mathrm{~B}$ & $3.20 \mathrm{~B}$ & $12.40 \mathrm{C}$ & $348.00 \mathrm{~B}$ & $216.00 \mathrm{~A}$ & $31.60 \mathrm{~A}$ & $7.42 \mathrm{~A}$ \\
$\mathrm{~W} 10$ & $11.80 \mathrm{~B}$ & $1.80 \mathrm{~B}$ & $21.20 \mathrm{~B}$ & $257.80 \mathrm{C}$ & $150.40 \mathrm{~B}$ & $31.40 \mathrm{~A}$ & $7.34 \mathrm{~A}$ \\
$\mathrm{SE} \pm$ & 1.67 & 0.75 & 1.07 & 18.44 & 15.24 & 0.28 & 0.06 \\
\hline
\end{tabular}

Means followed by the same letters in a column are significantly different at $\mathrm{P}(<0.05)$.

\section{Discussion of Results}

\section{1. $\mathrm{pH}$}

The intensity of acidity or alkalinity of water is determined by the power of hydrogen $(\mathrm{pH})$ present. Most chemical and biological reactions are determined by the $\mathrm{pH}$ present in the sampled water [39]. The $\mathrm{pH}$ values within the study area for the entire well ranged between 7.10 and 7.70 which show a slight trend of alkaline reaction within the study period of time. This is similar to the works of [1] [33] [40] [41] [42]. The highest values were obtained in W9 in the month of February during the study period which could be linked to the nature of rock underlay and the various activities that goes on around the area. The lowest value was observed at W8 for the same month of February. When compared with the standard values of [43] and [34], the values were observed to be within the limits. The variation observed in the samples shows that the water is alkaline in nature.

\subsection{Electrical Conductivity $(\mu \mathrm{s} / \mathrm{cm})$}

The type of ions present within water samples usually determines its amount of electrical conductivity. Depending on the electrical conductivity value of any water sample the quality of such water can be said to be either poor, medium or good [44] [45]. During the dry season of over a period of three years, the electrical conductivity ranged between 157 and $467 \mu \mathrm{s} / \mathrm{cm}$. The lowest value was observed at W6 for the month of January at $157 \mu \mathrm{s} / \mathrm{cm}$. Physico-chemical can be as a result of the presence of moisture in the various pores of soil. The highest value was observed as $467 \mu \mathrm{s} / \mathrm{cm}$ for the month of May which is described as the driest period of the year. This value could be linked to washing of the various salt added to the soil as fertilizers during the dry season farming. Though the maximum permissible limit recommended by [43] is $1000 \mu \mathrm{s} / \mathrm{cm}$. All samples considered for this study were within the permissible limit extremely.

\subsection{Total Hardness}

The formation of lather with soap in water determines the hardness property of such water which also increases the boiling point of water. Hardness of water depends mainly on the amount of calcium or magnesium salt or both present in the water sample [46] [47]. Hardness has been classified by [48] as follows: soft ( 0 to $60 \mathrm{mg} / \mathrm{l}$ ), moderately hard (61 to120 mg/l), hard (121 to $180 \mathrm{mg} / \mathrm{l}$ ) and 
above $180 \mathrm{mg} / \mathrm{l}$ as very hard. This is a major characteristic for determining the usability of water for domestic, drinking and many industrial purposes [5]. In this study, the value of hardness ranged between $32 \mathrm{mg} / \mathrm{L}$ to $142 \mathrm{mg} / \mathrm{L}$ which are within the permissible limit as prescribed by [34] and [43]. Any water containing excess hardness is not fit for portability as it is known to forms scales on water heater and cooking utensils when used for cooking. They are also known to consume more soap during washing of clothes. Thus, making such undesirable for use on less when properly treated for such purpose. This is similar to the works of [47].

\subsection{Temperature $\left({ }^{\circ} \mathrm{C}\right)$}

The observed temperature readings showed a significant trend of consistency throughout the study period. The results showed that the temperature ranged between $30^{\circ} \mathrm{C}$ and $33^{\circ} \mathrm{C}$. It has been established that temperature is one of the most important parameters for aquatic environments since all physical, chemical and biochemical properties depend on it. This work is similar to that carried out by [49] in Cross River State, Nigeria where they looked into the microbiological and physicochemical assessment of major sources of water for domestic uses in Calabar metropolis. This is also similar to the works of [1]. They carried out their studies for the same area but at different periods where they observed seasonal fluctuation of the well temperature which they linked to the variation in the climate of the area. Though the temperature recorded here were lower compared with this study location. All the observed values were within the recommended range of [34] and [50].

\subsection{Colour (pt.Co)}

Most of the water samples collected from the study area showed that the values were within the recommended values of [34]. The values ranged between 8.00 and $15.00 \mathrm{pt}$.Co. The values of W8 were observed to be extremely high which could be linked to the geology of the area. Thus, W8 may not be attractable for drinking purposes. The obtained results were similar to the works of [33] which investigated the quality assessment of shallow ground waters in selected agrarian communities in Patigi Local Government area of Kwara State and also the works of [51]. They worked on the water quality assessment of Otun and Ayetoro area of Ekiti State Southwestern Nigeria.

\subsection{Total Alkalinity}

The Total Alkalinity obtained for the various wells in the study area showed that W6, and W8 showed a gradual increase in the total alkalinity content while the others showed a cyclic trend. The maximum value was obtained at W8 with a value of $107.00 \mathrm{mg} / \mathrm{L}$ and $\mathrm{W} 6$ recorded the lowest value of $18.00 \mathrm{mg} / \mathrm{L}$. The total alkalinity of the water samples obtained from the Nyikangbe community were all found to be below the 200 maximum limit set by EPA, NSDQW and WHO. Al- 
kalinity less than $75 \mathrm{mg} / \mathrm{L}$ can make the water corrosive leading to potentially harmful metals dissolving in the water [43]. 95\% of the water samples obtained from the study areas had alkalinity lower than $75 \mathrm{mg} / \mathrm{L}$ which may have a potential effect on the water and the people that consume it. The values observed here were similar to the works of [1] [33] [52].

\subsection{Total Dissolved Solids (mg/L)}

According to [41], high TDS obtained from some wells can affect the taste of the drinking water which can lead to its consequent rejection by the public. The TDS for the various wells observed ranged between 120 and $298 \mathrm{mg} / \mathrm{L}$ for all the samples. The highest value was observed at W7 which could be linked to the initial rainfall of May within the study area while the lowest value was observed at W6 in the month of January. A trend of gradual increase in values was also observed for all the wells within the study area for the study period. This is similar to the works of [40] who studied the hydrogeochemical evaluation of shallow alluvial aquifer of WadiMarwani in western Saudi Arabia.

\subsection{Suspended Solids}

The maximum value of $39.00 \mathrm{mg} / \mathrm{L}$ for the suspended solids for the study location was observed at W8 for the month of March while the lowest value was observed at W6 for the month of January. From the data obtained, it was the values were cyclic in nature. This is similar to the works of [1] and [33]. The values were observed to be within the recommended standards of [43] and [50].

\subsection{Turbidity}

The maximum turbidity value as recommended by [43] and [50] is 5 NTU. Turbidity concentration of the various water samples from the study area ranged between $1 \mathrm{NTU}$ and $28 \mathrm{NTU}$. The maximum and minimum values were observed at study points W8 and W6, W7 and W10 for the months of April and January, April and March respectively. From the analysis carried out, it was observed that some of the wells where highly turbid. This implies that some level of treatment is required for the various wells within the study area. This similar to the works carried out by [53] and [54] who studied the Physicochemical Studies of Water from Selected Boreholes in Umuahia North Local Government Area, in Abia State and Physicochemical Quality of Treated and Untreated Borehole water in Kolokuma/Opokuma LGA, Bayelsa State, both in Nigeria. During their study, it was discovered that the turbidity values for the various wells though boreholes were cyclic in nature.

\subsection{Chemical Parameters}

It is observed in Table 1 that the concentrations of major dissolved constituents varied with respect to the location of the wells. This variance of the ionic concentration could indicate the involvement of several chemical processes and the 
geological formation of the area which can influence the water quality.

\subsubsection{Nitrate}

The nitrate content for the various wells ranged between 5.00 and $67.30 \mathrm{mg} / \mathrm{l}$ for all wells under study. A cyclic trend was observed in the set of data that were analyzed. This is similar to the works of [40] whose results of analyses were cyclic in nature. Wells W9 (May) and W10 (February, March, April and May) were observed to behave high concentration of Nitrates which exceeded the maximum permissible limits of [55] [56] and [34]. The other wells were observed to be within the recommended ranges. This is similar to the works of [49]. Reports have shown that Nitrate commonly occurs naturally in groundwater with the high concentration associated with human and animal waste, open septic or sewage systems and application of chemicals to farmlands. A combination of these processes can also be a major cause of high nitrate content in soils considering the growing population within the community and the poor sanitary facilities. This is similar to the submissions of [41] for studies carried out in rural communities of Benue State in Nigeria.

\subsubsection{Nitrite}

The highest mean concentration of Nitrate was recorded W7 in the month of May. This could be as a result of the initial rainfall that was observed within the month which means the nitrite compound must have been transported the well. The lowest value of $0.02 \mathrm{mg} / \mathrm{l}$ was observed in W6, W8, W9 and W10 for the months of March and February respectively. Wells having high values could be linked to transported solutes from farm lands within the proximity of the community. Some of the wells were observed values were found to be within the recommended values of [34] and [50].

\subsubsection{Chromium}

The values of Chromium in W6, W7, and W8 for the months of February and April and those of the months of March and May were observed to be above the permissible limits of [34] and [50]. This was linked to the various products that are being consumed in the various that litters around the environment. The main source of Chromium to most environments is paints on various packaging materials [33] [46] [47]. Long term exposure to chromium posed threat to human life and can cause kidney, liver circulatory and nerve tissue damages.

\subsubsection{Copper (mg/L)}

The maximum permissible limit of copper by [34] and [50] is $2 \mathrm{mg} / \mathrm{L}$. the results obtained from the study area shows that the copper content of the various wells ranges between 0.07 and $0.85 \mathrm{mg} / \mathrm{l}$. This similar to the initials for the same study carried out by Musa et al., 2013. This is considered an important nutritional requirement for human survival as lack of this can lead to anemia, skeletal defects, nervous breakdown and reproductive abnormalities. The values obtained were observed to be within the recommended values of [34] and [50]. This implies 
that the water sample here is fit for drinking.

\subsubsection{Iron (mg/L)}

Iron concentration for the various sampled wells ranges between 0.02 and 0.76 $\mathrm{mg} / \mathrm{L}$. The presence of iron in the study area could be linked to the washing of iron metals within short proximity of the wells and largely the geological formation of the area. The maximum permissible limits as recommended by [34] and [50] is $0.3 \mathrm{mg} / \mathrm{L}$. This shows that some of the wells had high content iron which requires remediation to make them suitable for drinking. W6, 8, 9 and 10 were observed to have high values of iron content. Though not considered as hazardous to health, it is considered to be an essential element for good health as it aids transportation in the blood of humans and animals. It is thus considered a secondary or aesthetic contaminant [56].

\subsubsection{Cyanide (mg/L)}

The existence of cyanide (Cy) in the groundwater in Minna, Nigeria could be linked to the enormous availability of gold in the catchment area. According to [57], the existence of Cyanide compounds in a watershed can be in the solid or the dissolved phase. They further stated that the solid-phase cyanide compounds can be easily detected at a site by their vivid blue color (e.g., blue colored wood chips associated with blue stained soil). The study area showed no traces of cyanide presence despite the commercial availability of gold in the region.

\subsubsection{Fluoride $(\mathrm{mg} / \mathrm{L})$}

The Fluoride $(\mathrm{mg} / \mathrm{L})$ content for the various groundwater ranged between 0.06 and $0.85 \mathrm{mg} / \mathrm{L}$ which was found to be within the permissible concentration limits of $1.0-1.5 \mathrm{mg} / \mathrm{L}$ according to WHO guideline [50]. Fluoride $\left(\mathrm{F}^{-}\right)$has a significant mitigating effect against dental caries if the concentration is approximately $1.0 \mathrm{mg} / \mathrm{L}$. However, continuing consumption of higher concentrations of $4 \mathrm{mg} / \mathrm{L}$ or more can cause dental fluorosis and in extreme cases even skeletal fluorosis. The measured level indicates acceptable situation in which the water samples may encourage healthy teeth if the well waters are used for drinking. The values obtained for the controlled samples compare favourably with those from the study area.

\subsubsection{Sulphur IV oxide ( $\mathrm{mg} / \mathrm{L})$}

The concentration of $\mathrm{SO}_{4}$ ranges from 1.50 to $7.30 \mathrm{mg} / \mathrm{L}$, the minimum value was recorded at W8(4) while the maximum was at W10(2), these ranges were below the permissible limit of WHO which is 400 and $500 \mathrm{mg} / \mathrm{L}$ respectively, these shows that the sampled well waters were fairly soft. This further explains the absence or low amount of carbonates and bicarbonates that may cause poor lather formation and scales in boilers.

\subsubsection{Magnesium (mg/L)}

Magnesium ion concentration obtained for the water ranged from a minimum of $0.10 \mathrm{mg} / \mathrm{l}$ to a maximum of $0.12 \mathrm{mg} / \mathrm{l}$ at both $\mathrm{W} 10$ (4 and 1) respectively. 
However considering these values of ranges, it is within the permissible limit for drinking water of $0.5 \mathrm{mg} / \mathrm{l}$ for [34] and [50] standard. This could be linked to its no direct contact with pipes and tap. $\mathrm{Mn}$ is an important element with moderate toxicity. It has been linked to neurological problems most especially when in large quantity.

\subsubsection{Calcium (mg/L)}

Calcium concentration ranges between 0.02 to $3.80 \mathrm{mg} / \mathrm{l}$ which falls in well W6(4) and W8(3), which is within the permissible limit for [56]. The dissolution of carbonate rocks enriches the water in $\mathrm{Ca}$ and $\mathrm{Mg}$ ions [58]. Gypsum dissolution releases $\mathrm{Ca}^{2+}$ and $\mathrm{SO}_{4}^{2-}$ consequently increases the $\mathrm{Ca}^{2+}$ concentration that leads to over saturation of the water in calcite $\left(\mathrm{CaCO}_{3}\right)$ due to common ion effect whereas release of sulfate $\left(\mathrm{SO}_{4}^{2-}\right)$, does not participate in the calcite equilibrium reaction. Dolomite is also present in the carbonate rock sand as calcite precipitates, dolomite dissolves. All three reactions; calcite precipitation, gypsum dissolution and dolomite dissolution lead to increase in $\mathrm{Mg}^{2+}$ and $\mathrm{SO}_{4}^{2-}$ concentration in spring water [58].

\subsubsection{Potassium $\left(\mathrm{PO}_{4}\right)$}

Potassium concentration ranges between 0.02 to $0.15 \mathrm{mg} / \mathrm{l}$ which falls in well W7(4) and W10(4), which is within the permissible limit for WHO which ranges between 0.02 and 0.35 as reported by [59]. He further suggests the mineral weathering and anthropogenic activities as major geochemical process leads to higher loading of $\mathrm{PO}_{4}, \mathrm{Na}, \mathrm{NO}_{3}, \mathrm{PO}_{4}$ and $\mathrm{Cl}$ would have common source such as animal waste, municipal waste and leaked sewer pipelines. Phosphate in the study area is mainly from poultry farm, livestock waste, fertilizers and detergent.

\subsubsection{Ammonia}

The concentration of ammonia ranges from 0.02 to $0.8 \mathrm{mg} / \mathrm{L}$ in well W8(3) and W8(1) respectively, these values were far below the [43] which is $600 \mathrm{mg} / \mathrm{L}$. According to [60] and [61], sources of ammonium include animal waste, municipal waste and poultry farm which are common features in the study area. Due to the increase of human activities globally, there had been a great increase in the presence of nitrogen and phosphorus in varying quantity in the soils [62]. This is dissolved into waters present within the soils to form ammonia thus increasing its presence in groundwater and other larger water bodies.

\subsubsection{Sodium (Na)}

Sodium concentration ranges from 1.50 to $7.30 \mathrm{mg} / \mathrm{L}$ for the minimum and maximum values in the study area, these falls in W7(2) and W7(5) respectively. These values fall below the [25] maximum permissible limit of $200 \mathrm{mg} / \mathrm{L}$. [63] stated that source of sodium is linked to weathering activities of rocks which dissolve into groundwater. The concentration of sodium in some location may be high due to erosion of salt deposits and sodium bearing rock minerals, naturally occurring brackish water of some aquifers, salt water intrusion into wells in 
coastal areas, infiltration of surface water contaminated by road salt, irrigation and precipitation leaching through soils high in sodium, groundwater pollution by sewage effluent and infiltration of leachate from landfills or industrial sites. Though a principle chemical in bodily fluids, it is not considered harmful at normal levels of intake from combined food and drinking water sources. However, increased intake of sodium in drinking water may be problematic for people with hypertension, heart disease or kidney problems that require them to follow a low sodium diet.

\subsection{Statistical Analysis}

The correlation analysis for groundwater in different locations of the study area for the two seasons was studied in detail. The statistical measures of the time series of water quality parameters for the various study areas as presented for the chemical and physical parameters in Table 4 and Table 5 respectively indicates that total alkalinity, calcium and total hardness were not significant at $\mathrm{P} \leq 0.05$ while other parameters had striking relationships with each other. This was not any different from the results obtained for the physical parameters. It is important to note that parameters with negative signs indicated no correlation between other parameters. The least significant difference for the chemical properties shows values with different letters were significantly different from each other at $\mathrm{P} \leq 0.05$ within each row. In the case of the physical properties, the various values that had the same letters in the column were significantly different at $\mathrm{P} \leq 0.05$

\section{Conclusion}

All the water quality parameters examined for well waters in Nyikangbe community, Chanchaga Local Government Area Niger State revealed that the well water is fairly soft, and has low level of trace metals and absence of microorganism that are harmful. It is recommended that the settlers/inhabitants can use their well water for domestic purposes and also advised to carry out analysis on the Well Water at least once every year because groundwater movement is usually slow, and polluted water may go undetected for a long time as most contamination is discovered only after drinking water has been affected and people become ill. Government should also involve health workers in giving awareness to inhabitants on use of safe water.

\section{Conflicts of Interest}

The authors declare no conflicts of interest regarding the publication of this paper.

\section{References}

[1] Musa, J.J., Nwabonyi, K.C., Aileku, P.Y., Popoola, P., Olatunde, O.J. and Olanipekun, O.B (2013) Comparative Analysis of Some Selected Deep and Shallow Wells in 
Niykangbe Community, Niger State. ARPN Journal of Science and Technology, 3, 626-632.

[2] Shen, L., Cheng, S., Gunson, A.J. and Wan, H. (2005) Urbanization, Sustainability and the Utilization of Energy and Mineral Resources in China. Cities, 22, 287-302. https://doi.org/10.1016/j.cities.2005.05.007

[3] Crouch, G.I. and Ritchie, J.R.B. (1999) Tourism, Competitiveness, and Societal Prosperity. Journal of Business Research, 44, 137-152. https://doi.org/10.1016/S0148-2963(97)00196-3

[4] Agrawal, A., Pandey, R.S. and Sharma, B. (2010) Water Pollution with Special Reference to Pesticide Contamination in India. Journal of Water Resource and Protection, 2, 432-448. https://doi.org/10.4236/jwarp.2010.25050

[5] Lee, D.R. (2005) Agricultural Sustainability and Technology Adoption: Issues and Policies for Developing Countries. American Journal of Agricultural Economics, 87, 1325-1334. https://doi.org/10.1111/j.1467-8276.2005.00826.x

[6] Jiang, Y. (2009) China's Water Scarcity: A Review. Journal of Environmental Management, 90, 3185-3196. https://doi.org/10.1016/j.jenvman.2009.04.016

[7] Jury, W.A. and Vaux Jr., H.J. (2007) The Emerging Global Water Crisis: Managing Scarcity and Conflict between Water Users. Advances in Agronomy, 95, 1-76. https://doi.org/10.1016/S0065-2113(07)95001-4

[8] Qadir, M., Boers, Th.M., Schubert, S., Ghafoor, A. and Murtaza, G. (2003) Agricultural Water Management in Water-Starved Countries: Challenges and Opportunities. Agricultural Water Management, 62, 165-185. https://doi.org/10.1016/S0378-3774(03)00146-X

[9] Niemczynowicz, J. (1999) Urban Hydrology and Water Management-Present and Future Challenges. Urban Water, 1, 1-14. https://doi.org/10.1016/S1462-0758(99)00009-6

[10] Stikker, A. (1998) Water Today and Tomorrow: Prospects for Overcoming Scarcity. Futures, 30, 43-62. https://doi.org/10.1016/S0016-3287(98)00005-6

[11] Gavrilescu, M., Demnerova, K., Aamand, J., Agathos, S. and Fava, F. (2015) Emerging Pollutants in the Environment: Present and Future Challenges in Biomonitoring, Ecological Risks and Bioremediation. New Biotechnology, 32, 147-156. https://doi.org/10.1016/j.nbt.2014.01.001

[12] Araújo, R.S., de Gloria Alves, M., de Melo, M.T.C., Chrispim, Z.M.P., Mendes, M.P. and Silva Júnior, G.C. (2014) Water Resource Management: A Comparative Evaluation of Brazil, Rio de Janeiro, the European Union, and Portugal: A Review. Science of the Total Environment, 511, 815-828. https://doi.org/10.1016/j.scitotenv.2014.11.098

[13] Singh, V., Khedun, C. and Mishra, A. (2014) Water, Environment, Energy, and Population Growth: Implications for Water Sustainability under Climate Change. Journal of Hydrologic Engineering, 19, 667-673. https://doi.org/10.1061/(ASCE)HE.1943-5584.0000866

[14] Carpenter, S.R., Stanley, E.H. and Vander Zanden, M.J. (2011) State of the World's Freshwater Ecosystems: Physical, Chemical, and Biological Changes. Annual Review of Environment and Resources, 36, 75-99. https://doi.org/10.1146/annurev-environ-021810-094524

[15] Biswas, A.K. (2008) Integrated Water Resources Management: Is It Working? International Journal of Water Resources Development, 24, 5-22. https://doi.org/10.1080/07900620701871718 
[16] Berndes, G. (2002) Bioenergy and Water-The Implications of Large-Scale Bioenergy Production for Water Use and Supply. Global Environmental Change, 12, 253-271. https://doi.org/10.1016/S0959-3780(02)00040-7

[17] Mahmood, A., Muqbool, W., WaseemMumtaz, M. and Ahmad, F. (2011) Application of Multivariate Statistical Techniques for the Characterization of Groundwater Quality of Lahore, Gujranwala and Sialkot (Pakistan). Pakistan Journal of Analytical \& Environmental Chemistry, 12, 102-112.

[18] Anku, Y.S., Banoeng-Yakubo, B., Asiedu, D.K. and Yidana, S.M. (2009) Water Quality Analysis of Groundwater in Crystalline Basement Rocks, Northern Ghana. Environmental Geology, 58, 989-997. https://doi.org/10.1007/s00254-008-1578-4

[19] Biswas, A.K. (2007) Water Management for Major Urban Centres. International Journal of Water Resources Development, 22, 183-197. https://doi.org/10.1080/07900620600690789

[20] Bhadja, P. and Vaghela, A. (2013) Assessment of Physico-Chemical Parameters and Water Quality Index of Reservoir Water. International Journal of Plant, Animal and Environmental Sciences, 3, 89-95.

[21] Greenlee, L.F., Lawler, D.F., Freeman, B.D., Marrot, B. and Moulin, P. (2009) Reverse Osmosis Desalination: Water Sources, Technology, and Today's Challenges. Water Research, 43, 2317-2348. https://doi.org/10.1016/j.watres.2009.03.010

[22] Oyanedel-Craver, V.A. and Smith, J.A. (2008) Sustainable Colloidal-Silver-Impregnated Ceramic Filter for Point-of-Use Water Treatment. Environmental Science \& Technology, 42, 927-933. https://doi.org/10.1021/es071268u

[23] Nielsen, D.L., Brock, M.A., Rees, G.N. and Baldwin, D.S. (2003) Effects of Increasing Salinity on Freshwater Ecosystems in Australia. Australian Journal of Botany, 51, 655-665. https://doi.org/10.1071/BT02115

[24] Herman, P.M.J. and Heip, C.H.R. (1999) Biogeochemistry of the Maximum Turbidity Zone of Estuaries (MATURE) Some Conclusions. Journal of Marine Systems, 22, 89-104. https://doi.org/10.1016/S0924-7963(99)00034-2

[25] WHO (1996) Water Quality Assessments-A Guide to Use of Biota, Sediments and Water in Environmental Monitoring. 2nd Edition, Chapman \& Hall, London, 122.

[26] Romero, D.M., Ríos de Molina, M.C. and Juárez, A.B. (2011) Oxidative Stress Induced by a Commercial Glyphosate Formulation in a Tolerant Strain of Chlorella kessleri. Ecotoxicology and Environmental Safety, 74, 741-747. https://doi.org/10.1016/j.ecoenv.2010.10.034

[27] Srinivasan, R. (2011) Advances in Application of Natural Clay and Its Composites in Removal of Biological, Organic, and Inorganic Contaminants from Drinking Water: Review Article. Advances in Materials Science and Engineering, 2011, Article ID: 872531. https://doi.org/10.1155/2011/872531

[28] Ocheri, M.I. and Ahola, O. (2015) Seasonal Variation in Physico-Chemical Characteristics of Rural Groundwater of Benue State, Nigeria. Journal of Asian Scientific Research, 2, 574-586. http://aessweb.com/journal-detail.php?id=5003

[29] Shihab, K. and Al-Chalabi, N. (2014) An Efficient Method for Assessing Water Quality Based on Bayesian Belief Networks. International Journal on Soft Computing, 5, 21-32. https://doi.org/10.5121/ijsc.2014.5203

[30] Ocheri, M.I., Odoma, L.A. and Umar, N.D. (2014) Groundwater Quality in Nigerian Urban Areas: A Review. Global Journal of Science Frontier Research: Environment \& Earth Science, 14, 34-45.

[31] Prasanna, M.V., Chidambaram, S. and Srinivasamoorthy, K. (2010) Statistical 
Analysis of the Hydrogeochemical Evolution of Groundwater in Hard and Sedimentary Aquifers System of Gadilam River Basin, South India. Journal of King Saud University (Science), 22, 133-145. https://doi.org/10.1016/j.jksus.2010.04.001

[32] Jokotagba, O.A., Shobo, A.O. and Onasanya, S.S. (2012) Assessment of Impact of Pit Latrine on the Physicochemical Properties of Well Water in OkeAgbo Area of Ijebu Igbo, Ogun State. Bulletin of Environment, Pharmacology and Life Sciences, 1, 16-19.

[33] Musa, J.J. and Ahanonu, J.J. (2013) Quality Assessment of Shallow Groundwater in Some Selected Agrarian Communities in Patigi Local Government Area, Nigeria. International Journal of Basic and Applied Science, 1, 548-563. https://doi.org/10.17142/ijbas-2012.1.3.10

[34] Nigerian Standard for Drinking Water Quality (NSDWQ) (2007) Nigerian Industrial Standard. NIS 554: 2007 ICS 13.060.20.

[35] APHA (2002) Standard Methods for the Examination of Water and Wastewater. 20th Edition, American Public Health Association. Baltimore, Maryland, USA,

[36] Horvat, M. (1993) Comparison of Distillation with Other Current Isolation Methods for the Determination of Methyl Mercury Compounds in Low Level Environmental Samples: Part II. Water. Analytica Chimica Acta, 282, 153-168. https://doi.org/10.1016/0003-2670(93)80364-Q

[37] Pfarrl, M.W., Horgan, G.W. and Dempfle, L. (2002) Relative Expression Software Tool (RESTC) for Group-Wise Comparison and Statistical Analysis of Relative Expression Results in Real-Time PCR. Nucleic Acids Research, 30, e36. https://doi.org/10.1093/nar/30.9.e36

[38] Gomez, K.A. and Gomez, A.A. (1984) Statistical Procedures for Agricultural Research. John Willey \& Sons, Hoboken.

[39] Azbar, N., Yonar, T. and Kestioglu, K. (2004) Comparison of Various Advanced Oxidation Processes and Chemical Treatment Methods for COD and Color Removal from a Polyester and Acetate Fiber Dyeing Effluent. Chemosphere, 55, 35-43. https://doi.org/10.1016/j.chemosphere.2003.10.046

[40] Al-ahmadi, M.E. and El-Fiky, A.A. (2009) Hydrogeochemical Evaluation of Shallow Alluvial Aquifer of WadiMarwani, Western Saudi Arabia. Journal of King Saud University (Science), 21, 179-190. https://doi.org/10.1016/j.jksus.2009.10.005

[41] Akaahan, T.J., Oluma, H.O.A. and Sha'Ato, R. (2010) Physico-Chemical and Bacteriological Quality of Water from Shallow Wells in Two Rural Communities in Benue State, Nigeria. Pakistan Journal of Analytical \& Environmental Chemistry, 11, 73-78.

[42] Jibrin, N.A., Mairami, F.M. and Husseini, H.U. (2015) Assessment of Groundwater Quality in Some Rural Areas of the Federal Capital Territory, Abuja, Nigeria. International Journal of Scientific Research and Education, 3, 3363-3376.

[43] WHO (2012) Progress on Drinking Water and Sanitation. World Health Organization, Geneva.

[44] Kannel, P.R., Lee, S., Lee, Y., Kanel, S.R. and Khan, S.P. (2007) Application of Water QualityIndices and Dissolved Oxygen as Indicators for River Water Classification and Urban Impact Assessment. Environmental Monitoring and Assessment, 132, 93-110. https://doi.org/10.1007/s10661-006-9505-1

[45] Jonnalagadda, S.B. and Mhere, G. (2001) Water Quality of the Odzi River in the Eastern Highlands of Zimbabwe. Water Research, 35, 2371-2376.

https://doi.org/10.1016/S0043-1354(00)00533-9 
[46] Singh, S., Rani, A., Mahajan, R.K. and Walia, T.P.S. (2003) Analysis of Uranium and Its Correlation with Some Physico-Chemical Properties of Drinking Water Samples from Amritsar, Punjab. Journal of Environmental Monitoring, 5, 917-921. https://doi.org/10.1039/b309493f

[47] Werner, J.J., Arnold, W.A. and McNeill, K. (2006) Water Hardness as a Photochemical Parameter: Tetracycline Photolysis as a Function of Calcium Concentration, Magnesium Concentration, and $\mathrm{pH}^{+}$. Environmental Science \& Technology, 40, 7236-7241. https://doi.org/10.1021/es060337m

[48] Durfor, C.N. and Becker, E. (1964) Public Water Supplies of the 100 Largest Cities in the United States, 1962 U.S. Geological Survey Water-Supply Paper 1812, 364 p. https://doi.org/10.1002/j.1551-8833.1964.tb01205.x

[49] Akubuenyi, F.C., Uttah, E.C. and Enyi-Idoh, K.H. (2013) Microbiological and Physicochemical Assessment of Major Sources of Water for Domestic Uses in Calabar Metropolis, Cross River State, Nigeria. Transnational Journal of Science and Technology, 3, 31-44.

[50] World Health Organization (WHO) (2005) Monitoring Bathing Waters-A Practical Guide to the Design and Implementation of Assessments and Monitoring Program. In: Bartram, J. and Rees, G., Eds., Sanitary Inspection and Microbiological Water Quality, World Health Organization, Geneva, 106-157.

[51] Ayodele, O.S. and Ajayi, A.S. (2015) Water Quality Assessment of Otun and Ayetoro Area, Ekiti State, Southwestern Nigeria. Advancement in Sciences and Technology Research, 2, 8-18.

[52] Ocheri, M.I. and Oklo, A. (2010) Seasonal Variation in Physico-Chemical Characteristics of Rural Groundwater of Benue State, Nigeria. Journal of Asian Scientific Research, 2, 574-586.

[53] Onwughara, N.I., Ajiwe, V.I.E. and Nnabuenyi, H.O. (2013) Physicochemical Studies of Water from Selected Boreholes in Umuahia North Local Government Area, in Abia State, Nigeria. International Journal of Pure \& Applied Bioscience, 1, 34-44.

[54] Sankar, R., Ramkumar, L., Rajkumar, M., Sun, J. and Ananthan, G. (2010) Seasonal Variations in Physico-Chemical Parameters and Heavy Metals in Water and Sediments of Uppanar Estuary, Nagapattinam, India. Journal of Environmental Biology, $31,681-686$.

[55] WHO/UNICEF (2004) Meeting the MDG Drinking Water and Sanitation: A Mid-Term Assessment of Progress. WHO/UNICEF, Geneva.

[56] WHO (2004) Rolling Revision of the WHO Guidelines for Drinking-Water Quality, Draft for Review and Comments. Nitrates and Nitrites in Drinking-Water, World Health Organization, WHO/SDE/WSH/04.08/56.

[57] Ghosh, R.S., Nakles, D.V., Murarka, I.P. and Neuhauser, E.F. (2004) Cyanide Speciation in Soil and Groundwater at Manufactured Gas Plant (MGP) Sites. Environmental Engineering Science, 21, 752-767. https://doi.org/10.1089/ees.2004.21.752

[58] Ansari, M.A., Archana, D., Kumar, U.S. and Vinod, S.K. (2015) Water Quality of Few Springs in Outer Himalayas-A Study on the Groundwater-Bed Rock Interaction Sand Hydrochemical Evolution. Groundwater for Sustainable Development, 1, 59-67. https://doi.org/10.1016/j.gsd.2016.01.002

[59] Raju, N.J., Priyanka, P., Deepa, G., Prahlad, R., Wolfgang, G. and Peter, W. (2016) Geochemical Assessment of Groundwater Quality in the Dun Valley of Central Nepal Using Chemometric Method and Geochemical Modeling. Groundwater for Sustainable Development, 5, 85-100. https://doi.org/10.1016/j.gsd.2016.02.002 
[60] Edwards, D.R. and Daniel, T.C. (1992) Environmental Impacts of On-Farm Poultry Waste Disposal-A Review. Bioresource Technology, 41, 9-33. https://doi.org/10.1016/0960-8524(92)90094-E

[61] Hooda, P.S., Edwards, A.C., Anderson, H.A. and Miller, A. (2000) A Review of Water Quality Concerns in Livestock Farming Areas. Science of the Total Environment, 250, 143-167. https://doi.org/10.1016/S0048-9697(00)00373-9

[62] Howarth, R.W., Sharpley, A. and Walker, D. (2002) Sources of Nutrient Pollution to Coastal Waters in the United States: Implications for Achieving Coastal Water Quality Goals. Estuaries and Coasts, 25, 656-676.

https://doi.org/10.1007/BF02804898

[63] Oliva, P., Dupre, B., Martin, F. and Viers, J. (2004) The Role of Trace Minerals in Chemical Weathering in a High-Elevation Granitic Watershed (Estibère, France) Chemical and Mineralogical Evidence. Geochimica et Cosmochimica Acta, 68, 2223-2243. https://doi.org/10.1016/j.gca.2003.10.043 